Z Badań nad Książką i Księgozbiorami Historycznymi 2019. T. specjalny: Dla Niepodległej The Studies into the History of the Book and Book Collections 2019. Special issue: For an Independent Poland

Krzysztof Kofin

https://doi.org/10.33077/uw.25448730.zbkh.2020.212

Uniwersytet Papieski Jana Pawła II w Krakowie

krzysztof.kofin91@gmail.com

ORCID 0000-0002-8745-6523

\title{
Historia plagiatów Wincentego Rzymowskiego odkrytych na łamach tygodnika „Prosto z Mostu”
}

\author{
Abstract \\ History of Wincenty Rzymowski’s plagiarism discovered \\ in the weekly "Prosto z Mostu"
}

The article presents stories of plagiarisms committed by Wincenty Rzymowski, a leading Polish journalist of the interwar period, the editor-in-chief of "Kurier Poranny" and a member of the Polish Academy of Literature. Plagiarism was discovered by the editors of the right-wing weekly "Prosto z Mostu", edited and published by Stanisław Piasecki. Rzymowski in his journalism used excerpts from the work of the British thinker Bertrand Russell In Praise of Idleness and excerpts from the article of the French journalist Jean Prèvost, discussing the position of England against the Italian-Abyssinian conflict. The article focuses on the scope of plagiarism, the reactions of the Polish daily press and cultural weeklies, national, catholic, liberal-left and satirical, as well as the effects of the ruling of the Polish Academy of Literature, which pronounced on the accusation in consequence of which Rzymowski gave up from membership in Academy.

Key words: plagiarism - Polish Academy of Literature - press of the Second Polish Republic Wincenty Rzymowski - Bertrand Russell.

Słowa kluczowe: plagiat - Polska Akademia Literatury - prasa II Rzeczypospolitej - Wincenty Rzymowski - Bertrand Russell.

„Z Badań nad Książką i Księgozbiorami Historycznymi” - Udział zagranicznych recenzentów w ocenie publikacji; Stworzenie anglojęzycznej wersji wydawniczej publikacji; Digitalizacja tomów archiwalnych rocznika w celu zapewnienia otwartego dostępu do nich przez Internet oraz wdrożenie i utrzymanie cyfrowej platformy redakcyjnej - zadanie finansowane w ramach umowy nr 653/P-DUN/2019 ze środków Ministra Nauki i Szkolnictwa Wyższego przeznaczonych na działalność upowszechniającą naukę. 
Okres międzywojnia to czas rywalizacji dwóch wielkich, przeciwstawnych bloków politycznych: obozu piłsudczykowskiego, który po przewrocie majowym wprowadził w II RP system quasi-autorytarny, i Narodowej Demokracji, kierowanej przez Romana Dmowskiego. Konflikt oprócz sceny parlamentarnej objął także wyższe uczelnie i łamy prasy, walczącej nie tylko o kształt państwa, lecz również o charakter polskiej klasy inteligenckiej, kultury i sztuki, stanowiącej znakomity nośnik ideologii.

$\mathrm{W}$ drugiej połowie lat 30. XX w. głównym czasopismem reprezentującym ideę narodową stał się tygodnik „Prosto z Mostu”" który z niedzielnego, trzyletniego dodatku literackiego dziennika „ABC”, wyodrębnił się w 1935 r. jako samodzielne pismo ${ }^{2}$ redagowane i wydawane przez Stanisława Piaseckiego, słynącego z antysanacyjnych poglądów i krytyki grupy literackiej Skamander ${ }^{3}$. Trzon pisma stanowili cenieni publicyści i poeci, jak Adolf Nowaczyński, Kazimiera Iłłakowiczówna, Konstanty Ildefons Gałczyński, Karol Zbyszewski i Jan Dobraczyński, a także działacze związani z obozem narodowym: Jerzy Zdziechowski, Jan Mosdorf, Jan Korolec, Wojciech Wasiutyński i Adam Doboszyński. Na treść tygodnika, liczącego stale osiem stron (z wyjątkiem numerów świątecznych), składały się artykuły na temat zagadnień literatury i sztuki, utwory oryginalne, bogaty dział informacyjny, przegląd wydarzeń kulturalnych z całego tygodnia i polityczno-społeczna publicystyka. Ambicją Piaseckiego było stworzenie nowoczesnego, bogato ilustrowanego czasopisma dostępnego dla każdego czytelnika, w czym pomóc miała niska cena tygodnika ${ }^{4}$.

Celem niniejszego artykułu, opartego na analizie zawartości treści ukazujących się w polskiej prasie codziennej oraz tygodnikach kulturalnych o charakterze narodowym, katolickim, liberalno-lewicowym i satyrycznym w drugiej połowie lat 30. XX w. jest przedstawienie historii plagiatów Wincentego Rzymowskiego, odkrytych przez redakcję tygodnika „Prosto z Mostu”, reakcji prasy i skutków orzeczenia Polskiej Akademii Literatury (PAL), która wypowiedziała się w przedmiocie oskarżenia. Sprawa plagiatu, którego dopuścił się akademik, została poruszona w obszernej monografii Lucyny Chmielewskiej Wincenty Rzymowski (1883-1950). Biografia publicysty i polityka. Autorka

\footnotetext{
1 R. Łętocha, „Prosto z Mostu” - pismo i środowisko, [w:] Prasa Narodowej Demokracji 18861939, red. A. Dawidowicz, E. Maj, Lublin 2010, s. 111-125.

2 S. Piasecki, Jak powstało „Prosto z mostu”, „Prosto z Mostu” 1935, nr 1, s. 1.

3 M. Tobera, ,Antyskamandryta” (Stanistaw Piasecki), „Kwartalnik Historii Prasy Polskiej” 1992, t. 31, nr 3-4, s. 188-195; M. Urbanowski, „Fanatyk patriotyzmu”- portret Stanistawa Piaseckiego, [w:] S. Piasecki, Prosto z mostu. Wybór publicystyki literackiej, wybór i oprac. M. Urbanowski, Kraków 2003, s. 87-98; M. Urbanowski, O Stanisławie Piaseckim i jego krytyce literackiej, [w:] M. Urbanowski, Prawą strona literatury polskiej. Szkice i portrety, Kraków 2007, s. 7-49.

4 Początkowa cena wynosiła $30 \mathrm{gr}$, by ukształtować się ostatecznie na poziomie $50 \mathrm{gr}$, co nie zmieniało faktu, że tygodnik pozostał wyraźnie tańszy niż konkurencyjne „Wiadomości Literackie”, które kosztowały aż 80 gr.
} 
pracy jednoznacznie neguje celowość plagiatu Rzymowskiego, thumacząc go zbieżnością poglądów akademika z myślą prezentowaną przez Bertranda Russella ${ }^{5}$. Chmielewska, poświęcając oskarżeniom o plagiat dużo uwagi, nie oddaje w pełni zasięgu medialnej burzy, którą wywołał demaskujący artykuł J. Mosdorfa opublikowany w 1936 r. w „Prosto z Mostu”. Skupiła się przede wszystkim na relacjach prasowych pism związanych z nurtem narodowym, bagatelizując lub pomijając szereg ogólnopolskich czasopism, które kategorycznie opowiedziały się przeciwko korzystnemu dla plagiatora orzeczeniu Akademii. Nie wspomina również o krytyce wymierzonej w Rzymowskiego na łamach pism katolickich (jak np. „Przegląd Katolicki”) i satyrycznych („Mucha” i „Szarża”). Ponadto pomija reakcję Związku Dziennikarzy RP, który potępił wyrok PAL i metody pracy dziennikarskiej akademika.

Głównym celem, jaki Piasecki postawił przed pismem „Prosto z Mostu”, była walka o kształt polskiego życia kulturowego z liberalno-lewicowymi „Wiadomościami Literackimi” Mieczysława Grydzewskiego oraz PAL, W szczególności jej prezesem, Wacławem Sieroszewskim. W rywalizacji tej redakcja „Prosto z Mostu” nie stroniła od radykalnych metod, wytaczając PAL szereg procesów sądowych czy oskarżając kolejnych jej członków o plagiat, który w polskim ówczesnym prawodawstwie nie funkcjonował jako pojęcie prawne. Same procesy dotyczące oskarżeń o plagiat były niezwykłą rzadkością, gdyż ścigano je wyłącznie z oskarżenia prywatnego twórcy, któremu plagiator wyrządził szkodę w zakresie jego osobistego stosunku do dzieła ${ }^{6}$. Jednym z najgłośniejszych plagiatów II RP, odkrytym przez J. Mosdorfa, był plagiat którego dopuścić miał się W. Rzymowski, uznany tłumacz, publicysta i redaktor naczelny „Kuriera Porannego”.

\section{Oskarżenie o plagiat Wincentego Rzymowskiego}

Tygodnik „Prosto z Mostu”, jednoznacznie utożsamiający się z poglądami endeckimi, od początku istnienia poddawał krytyce Polską Akademię Literatury, wzorowaną na jej francuskim odpowiedniku, powołaną do życia 29 IX 1933 r., jako instytucję mającą - we współpracy z rządem - zatroszczyć się o podniesienie poziomu polskiej literatury ${ }^{7}$. Wśród 15 dożywotnich członków PAL obiektem częstej krytyki był W. Rzymowski ${ }^{8}$, któremu - według Piaseckiego - wyłącznie prorządowa publicystyka, ,przedwczorajsza w formie

\footnotetext{
5 L. Chmielewska, Wincenty Rzymowski (1883-1950). Biografia publicysty i polityka, Toruń 2007, s. 250-251.

6 O. Missuna, Warszawski pitaval literacki, Warszawa 1960, s. 147.

7 Rozporządzenie Rady Ministrów z dnia 29 września 1933 r. o Polskiej Akademii Literatury, M.P. 1933, nr 234, poz. 254.

8 Na marginesie, „Prosto z Mostu” 1935, nr 40, s. 6.
} 
i pustosłowa", zapewniła miejsce w Akademii ${ }^{9}$. Rzymowskiego krytykowano także za jego stosunek do marksizmu, prokomunistyczną publicystykę ${ }^{10}$, a w szczególności za udział w Kongresie Pracowników Kultury we Lwowie 16-17 V 1936 r., zorganizowanym przez Komunistyczną Partię Polski ${ }^{11}$, co wywołało wzburzenie m.in. Ksawerego Pruszyńskiego ${ }^{12}$. Ponownie został skrytykowany, gdy na łamach „Kuriera Porannego” w artykule „Ptomyk” światta i chmura mroku wziął w obronę pismo „Płomyk”, przeznaczone dla młodzieży a wydawane przez Związek Nauczycielstwa Polskiego (ZNP), którego 25. numer z 1936 r. był w całości poświęcony ZSRR. Rzymowski, nie zważając na powszechną krytykę ZNP w ogólnopolskiej prasie i powszechne oskarżenia jego pisma o płatną propagandę ustroju komunistycznego pisał, że rozproszy ono ,chmurę wielkiego mroku; może zdoła nam oświecić bezdroża, na jakie zbłądzić może prasa i publicystyka, gdy niewybredność kryteriów połączy się w niej z żądzą tanich demagogicznych powodzeń" "13. Według Rzymowskiego „Płomyk” w opisie ZSRR odrzucał stanowisko, wedle którego jedynym źródłem wiedzy o komunistycznym sąsiedzie są agitacyjne ulotki oraz zachował równowagę i bezstronność, gdyż zamieścił w numerze wiersze, opowiadania i ilustracje z życia polskich zesłańców ${ }^{14}$. Wyrażał też troskę o młodego czytelnika, by ten nie popadł w nienawiść „,do Rosji obecnej, z którą łączy nas pakt nieagresji i z którą polska racja stanu każe nam żyć w pokoju i zgodzie sąsiedzkiej”'15. W reakcji na artykuł Rzymowskiego „Prosto z Mostu” w numerze 28 z 12 VII 1936 r. zamieściło fragmenty Listu otwartego do członków Zwiąku Nauczycielstwa Polskiego Antoniego Madeja (byłego członka ZNP i byłego redaktora „Małego Płomyczka”), oskarżającego akademika i „Kurier” o łapówkarstwo:

Za artykuł w obronie „Płomyka” otrzymał zł. 500, bo jest spec od demokracji i konserwy! A specjalny numer dziennika, zawierający obronę „Płomyka” i rozesłany do wszystkich

S. Piasecki, Wawrzyn akademicki przedstawia się..., „Prosto z Mostu” 1935, nr 47, s. 1.

10 Sprawa otrzymania przez Rzymowskiego 500 zł za artykuł broniący Związek Nauczycielstwa Polskiego i jego pismo „Płomyk” została poruszona na łamach „Prosto z Mostu”, zob. Na marginesie, ,Prosto z Mostu” 1936, nr 29, s. 1; Z. Broncel, To, czego nie było w sprawozdaniu P.A.L.-u, „Prosto z Mostu” 1936, nr 49, s. 4.

11 S. Piasecki, Front sowiecki i front polski, „Prosto z Mostu” 1936, nr 23, s. 1.

12 Publicysta „Ilustrowanego Kuriera Codziennego”, zarzucał akademikowi czołobitność wobec sanacyjnej władzy przy równoczesnej pochwale marksizmu, zob. K. Pruszyński, „Pomiędzy Marksem a... każdorazowym premierem”. ,Akademik literatury” Wincenty Rzymowski w świetle faktów. Do Pana Mariana Dąbrowskiego, Naczelnego Redaktora „IKC” list otwarty, „Ilustrowany Kurier Codzienny" 1936, nr 169, s. 2-3.

13 W. Rzymowski, „Plomyk” światta i chmura mroku, „Kurier Poranny” 1936, nr 76, s. 1.

14 W „Kurierze Porannym” z 1936 r. w nr 76 na s. 6 zamieszczono także artykuły: Czemu stuży „Plomyk”; H. Marczewska, W otwarte karty; Pobożne życzenia K.A.P.-u; H. Ładosz, „Tajny detektyw" dmucha.

15 W. Rzymowski, ,Ptomyk”..., s. 1. 
związkowców, też zrobił dobry interes, bo i reklama była i koszta tej reklamy pokrył ZNP (około $5.000 \mathrm{zł}$.) $)^{16}$.

W atmosferze skandalu, jaki wywołał udział Rzymowskiego w zjeździe lwowskim i jego obrona pisma „Płomyk”, założyciel Obozu Narodowo-Radykalnego J. Mosdorf, ukrywający się pod pseudonimem Andrzej Witowski, w numerze 42 „Prosto z Mostu” z 27 IX 1936 r. zamieścił recenzję książki Rzymowskiego Prawo do życia a powinność pracy, w której stwierdził, że poglądy autora:

są w najlepszym wypadku poprawnymi komunałami, przeważnie zaś nieznośnie płytkimi i demagogicznymi frazesami, przeczącymi zasadom logiki lub gospodarstwa. Tupet autora i umiejętność spłycania zagadnień jest wręcz imponująca ${ }^{17}$.

Mosdorf poddawał krytyce tezy Rzymowskiego dotyczące m.in. skrócenia 40-godzinnego tygodnia pracy czy próby przeniesienia do polskiej gospodarki rozwiązań zaczerpniętych ze Stanów Zjednoczonych Ameryki. Refleksja nad pracą Rzymowskiego pozwoliła Mosdorfowi na odkrycie znaczących podobieństw do wniosków zawartych w dziele angielskiego myśliciela Bertranda Russella Pochwała próżniactwa, wydanym w Polsce zaledwie kilka tygodni po książce Rzymowskiego ${ }^{18}$. Mosdorf, doskonale zdając sobie sprawę, że praca Russella ukazała się w języku angielskim po raz pierwszy w 1935 r., ogłosił w numerze 47 pisma z 8 listopada, w pełnym ironii artykule Bertrand Russell plagiatorem?, że to brytyjski pisarz dopuścił się plagiatu ${ }^{19}$. Na poparcie swych tez zestawił sporne fragmenty pracy Prawo do życia... W. Rzymowskiego ${ }^{20}$ z Pochwała próżniactwa B. Russella ${ }^{21}$. Z ich porównania jasno wynikało, że Rzymowski przypisał sobie wnioski Russella dotyczące rozwoju ówczesnej techniki, która w wielkim stopniu miała przyczynić się do redukcji ilości pracy gwarantującej zaspokojenie minimum potrzeb ludzkich ${ }^{22}$. Ponadto akademik „,wykorzystał” w swej pracy pogląd Brytyjczyka, że przy pomocy naukowej organizacji produkcji także po wojnie mógł zostać utrzymany jej wysoki poziom, przy jednoczesnym skróceniu dnia pracy w celu uniknięcia chaosu gospodarczego ${ }^{23}$. Rzymowski ,stwierdził” za Russellem, że dalszy rozwój techniki i kapitalistyczna konieczność utrzymania produkcji określonych dóbr i usług

16 Wycinanki, „Prosto z Mostu” 1936, nr 28, s. 3.

17 A. Witowski [właść.: Jan Mosdorf], W okopach zeszłego stulecia, „Prosto z Mostu” 1936, nr 42 , s. 7.

18 Oryginalna pisownia nazwiska autora brzmi Russell, podczas gdy polska prasa konsekwentnie pisała Russel. nr 47, s. 1 .

19 A. Witowski [właść.: Jan Mosdorf], Bertrand Russel plagiatorem?, „Prosto z Mostu” 1936 ,

20 W. Rzymowski, Prawo do życia a powinność pracy, Warszawa 1936, s. 65-70.

21 B. Russell, Pochwała próżniactwa, Warszawa 1936, s. 13-14.

22 W. Rzymowski, Prawo do życia..., s. 65.

23 Tamże, s. 67. 
przy zachowaniu dotychczasowego czasu pracy doprowadzi do nadprodukcji i ostatecznie przyczyni się do bankructwa wielu przedsiębiorstw i masowego bezrobocia ${ }^{24}$. Rzymowski nie ograniczył się wyłącznie do przywłaszczenia wniosków Russella, ale również jego poetyckich metafor, jak np. o niemożliwości skonsumowania chleba, który jeszcze nie został wypieczony ${ }^{25}$. W innym miejscu dzieła Prawo do życia ... akademik wprowadził zaledwie jedną zmianę, pisząc: „Wyobraźmy sobie, że w danej chwili pewna liczba robotników zatrudniona jest w produkcji igieł do szycia" 26 , podczas gdy w oryginale zdanie brzmiało: „Przypuśćmy, że w danej chwili pewna liczba ludzi zajęta jest produkcją szpilek"27. Warto podkreślić, że plagiat Rzymowskiego nie był rozległy, gdyż dotyczył zaledwie kilku stron. Mosdorf jednak uznał, że w tej sprawie nie należy milczeć. Kpił, że PAL powinna podjąć uchwałę o sądownym ściganiu Russella, który „okradł” Rzymowskiego i należy mu się kara, „bo chyba nie będzie miał czoła dowodzić, że to on jest ofiarą plagiatu"28.

Oskarżony o plagiat zareagował natychmiast. Na łamach „Kuriera Porannego" z 8 XI 1936 r. w artykule Bandycka napaść „Prosto z mostu” Rzymowski stwierdzał, że od dłuższego czasu Piasecki i redakcja tygodnika, ,gorliwie węszą, co by się dało - znaną zresztą metodą - podrzucić mi, jako rzecz, mogącą poderwać w oczach opinii zaufanie do mojego stanowiska i do mego pióra, widocznie bardzo dla nich niedogodnego" 29 . Według akademika, „Prosto z Mostu" dla udowodnienia plagiatu wskazało zaledwie kilka stron wyrwanych z szerszego kontekstu, podczas gdy obie książki miały nie mieć ze sobą nic wspólnego:

Kartki, którymi potrząsa p. Piasecki [...] mają w rozważaniach moich znaczenie epizodyczne: zawierają w sobie przykład, ilustrujący niedorzeczności i paradoksy, do których stosunki we współczesnym życiu gospodarczym doprowadza masowe bezrobocie. Treść rozdziału mej książki zachowałyby swoją wymowę i bez tego przykładu, który należy po prostu do abecadła w konspekcie nowoczesnej myśli ekonomicznej, przez samego zaś Russella, a zaczerpnięty został nie skądinąd tylko z enuncjacji i roczników Międzynarodowego Biura Pracy, na których i ja swoje zasadnicze wywody oparłem ${ }^{30}$.

Nie dostrzegając własnej winy, Rzymowski zaatakował swoich krytyków -Piaseckiego, odkrywcę plagiatu J. Mosdorfa i. A. Doboszyńskiego, jako czołowych ideologów pisma, po czym, próbując oczyścić się z zarzutów, przedstawił sporny rozdział swego dzieła, konfrontując go z rzekomo splagiatowanym

\footnotetext{
24 Tamże, s. 70.

25 Tamże, s. 65.

26 Tamże, s. 68.

27 B. Russell, dz. cyt., s. 14.

28 A. Witowski [właść.: Jan Mosdorf], Bertrand Russel..., s. 1.

29 W. Rzymowski, Bandycka napaść „Prosto z mostu”, „Kurier Poranny” 1936, nr 311, s. 5.

30 Tamże.
} 
tekstem Russella. Następnie w krótkim felietonie Pod adresem p. Piaseckiego akademik postawił się w pozycji ofiary ataku redaktora „Prosto z Mostu”, który oskarżenia o plagiat używał jako broni przeciwko swoim politycznym oponentom $^{31}$.

\section{Prasa wobec plagiatu Rzymowskiego}

Sprawa plagiatu Rzymowskiego odbiła się szerokim echem w polskiej prasie. We fragmentach artykuł J. Mosdorfa przedrukowano m.in. w „Chwili”, „Czasie”, „Słowie”, „Warszawskim Dzienniku Narodowym”, „Kurierze Nowogrodzkim”, „Kurierze Wileńskim” i „ABC. Nowiny Codzienne”32, w którym za kontrolę treści politycznych odpowiadał J. Korolec, jeden z głównych ideologów ONR-ABC, w 1935 r. czołowy publicysta „Prosto z Mostu”. W numerze 321 tego dziennika z 8 XI 1936 r. czytamy, że

niepoważne snoby publicystyczne nie są zdolne do samodzielnej myśli twórczej. [...] Jeden przepisuje dosłownie, inny z takimi zmianami, że plagiat trudno udowodnić, ale niewolnictwo duchowe u obcych w obu wypadkach jednakowe ${ }^{33}$.

W numerze 322 „ABC”, Rzymowski przedstawiony został jako redaktor dwulicowy, który poddając krytyce kapitalizm, nie stronił od zamieszczania reklam firm reprezentujących ciężki przemysł. Ponadto dziennik stawiał kluczowe pytanie: „Bo cóż p. Rzymowskiemu szkodziło wstawić trzy słowa: «jak pisze Russell»?"34. W numerze 333 redakcja „ABC”35 stanęła w opozycji wobec Samuela Hirszhorna, który na łamach żydowskiego „Naszego Przeglądu” pisał o Rzymowskim, że jego książka w znakomity sposób demaskuje faszyzm, szowinizm i rasizm, obecny nie tylko w III Rzeszy i faszystowskich Włoszech, ale także w Polsce ${ }^{36}$. Hirszhorn uważał Rzymowskiego za reformatora głoszącego postęp, czym według „ABC” zasłużył sobie na fotel członka PAL. W numerze $336 \mathrm{w}$ prześmiewczym tonie pismo „ABC” ogłosiło, że Rzymowski początkowo planował wspomnieć o B. Russellu ${ }^{37}$, aby w kolejnym numerze stwierdzić, że akademik zamierzał rozwiązać

\footnotetext{
31 W. Rzymowski, Pod adresem p. Piaseckiego, „Kurier Poranny” 1936, nr 311, s. 6.

32 Czy akademik Rzymowski popetnit plagiat?, „Chwila” 1936, nr 6336, s. 4; P. Rzymowski pod zarzutem, „Czas” 1936, nr 309, s. 3; „Prosto z Mostu”. Bertrand Russell plagiatorem?, „Kurier Nowogrodzki” 1936, nr 307, s. 7; Agentura obcej myśli. Czas skończyć z rzymowszczyzna, „ABC. Nowiny Codzienne” 1936, nr 321, s. 2; Rzymowski plagiatorem, „Warszawski Dziennik Narodowy” 1936, nr 307B, s. 2.

33 Agentura obcej myśli..., s. 2.

34 P. Rzymowski się ttumaczy, „ABC. Nowiny Codzienne” 1936, nr 322, s. 3.

35 Bobki nie wystarcza, „ABC. Nowiny Codzienne” 1936, nr 333, s. 3.

36 S.H. [Samuel Hirszhorn], Przez skandal do postepu!, „Nasz Przegląd” 1936, nr 334, s. 3.

37 Zwrot w sprawie Rzymowskiego. Akademia Literatury powołała specjalna komisje, „ABC. Nowiny Codzienne" 1936, nr 336, s. 1.
} 
sprawę plagiatu w rodzinnym gronie PAL, którego statut umożliwiał usunięcie członka wskutek popełnienia czynu haniebnego, m.in. plagiatu, podsumowując, że Rzymowski dobrowolnie powinien opuścić szeregi Akade$\mathrm{mii}^{38}$. Noworoczny horoskop „ABC” sugerował nawet, że redaktor „Kuriera Porannego" „zostanie rejentem i otworzy kancelarię notarialną. [...] Jako wybitnie dokładny w przepisywaniu" ${ }^{39}$.

Drugim pismem, które jednoznacznie stanęło po stronie „Prosto z Mostu” był blisko związany z obozem narodowym „Warszawski Dziennik Narodowy". Na jego łamach pisano, że plagiat Rzymowskiego jest oczywisty i nie może zostać zatuszowany, zwłaszcza gdy ,nabiera on osobliwego posmaku ze względu na osobę p. Rzymowskiego, strojącego się w pozę Katona, prawiącego moralne kazania i cieszącego się dużym uznaniem w kołach sana-

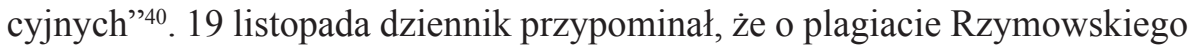
zaczęły pisać zagraniczne pisma, podczas gdy PAL wciąż nie podjęła kroków mających na celu jego usunięcie ze swojego grona ${ }^{41}$. W numerze 335 z 6 grudnia stwierdzono, że po stronie Rzymowskiego stanęło masońskie pismo „Epoka” uznające, że atak na akademika ma podłoże antysemickie ${ }^{42} . Z$ kolei prorządowy „Ilustrowany Kurier Codzienny” z 9 XI 1936 r. zastanawiając się nad dotychczasowymi dokonaniami akademika uznał, że „nic ciekawego nie napisał, a jednak jest «znakomity». Nic nie tworzy - a uznany. Nie pracuje na miejsce w historii literatury, a ma fotel w Polskiej Akademii Literatury"43. Krakowski dziennik w duchu pełnym ironii ogłosił, że PAL musiała znać jego „tajne dokonania”, które splagiatował sam Russell, zdecydowanie domagając się usunięcia Rzymowskiego z Akademii, bowiem przestał być wiarygodny dla opinii publicznej ${ }^{44}-22$ XI 1936 r. przytoczył jeden z krótkich wierszyków-nekrologów „,pisanych” przez Rzymowskiego: „Tu spoczął człowiek, który za życia miał dwie córy. Sławę i mądrość: obie legły przed ojcem w grobie"45. Natomiast Julian Babiński na łamach „Merkuriusza Polskiego Ordynaryjnego” z 15 XI 1936 r., pisał w prześmiewczym tonie, że:

nie tylko faszyści okradli p. Rzymowskiego ze spodni (sztuczkowych). [...] Kto żyje, kradnie p. Rzymowskiego. Nawet Bertrand Russell oderżnął całe stronnice z p. Rzymowskiego.

\footnotetext{
38 Sprawa p. Rzymowskiego. Sad honorowy orzeknie, czy plagiat jest czynem haniebnym, „ABC. Nowiny Codzienne” 1936, nr 337, s. 1.

39 Przepowiednie na rok 1937, „ABC. Nowiny Codzienne” 1937, nr 3, s. 8.

40 Rzymowski plagiatorem, dz. cyt.

41 Echa plagiatu zagranica, ,Warszawski Dziennik Narodowy” 1936, nr 318B, s. 4.

42 Przeglad prasy, „Warszawski Dziennik Narodowy” 1936, nr 335B, s. 3. O masonerii chroniącej W. Rzymowskiego pisano także w „Prosto z Mostu” 1936, nr 52, s. 1.

43 Bezwstydny Russel. „Akademik” Rzymowski „ofiarq” plagiatu angielskiego autora, „Ilustrowany Kurier Codzienny" 1936, nr 312, s. 5.

44 Tamże.

45 Nagrobek sobie samemu, „Ilustrowany Kurier Codzienny” 1936, nr 325, s. 15.
} 
A zdawałoby się, że tak sławny, taki wielki Bertrand Russell nie powinien popełniać takich paskudnych kradzieży, jak literackie ${ }^{46}$.

W czasie wzmożonych ataków prasy na Rzymowskiego w numerze 50 „Prosto z Mostu" z 29 XI 1936 r. odkryto jego drugi plagiat. W niepodpisanym artykule Dalsze źródła publicystyki Rzymowskiego. Nie tylko Russell, ale i Jean Prèvost ${ }^{47}$ redakcja ogłosiła, że artykuł akademika Ostatnie minuty i sekundy ${ }^{48}$ zamieszczony 1 IX 1935 r. w „Kurierze Porannym”, omawiający aktualne stanowisko Anglii wobec konfliktu włosko-abisyńskiego, jest plagiatem z J. Prèvosta. Tekst tego specjalnego korespondenta paryskiego tygodnika „Marianne” w Londynie ukazał się 28 VIII 1935 r. (nr 149), stąd dla „Prosto z Mostu” nie ulegało wątpliwości, że Rzymowski po raz kolejny wykorzystał wieloletnie doświadczenie w pracy tłumacza, aby użyć cudzego tekstu we własnej publicystyce. Dlatego zawarte w nim tezy o wyższości Anglii nad Włochami, jej olbrzymim, wręcz niewyczerpanym potencjale ekonomicznym i surowcowym czy bliskim sojuszu ze Stanami Zjednoczonymi Ameryki, należy uznać za poglądy Francuza. Według „Prosto z Mostu” Rzymowski wprowadził zaledwie jedną zmianę w stosunku do tekstu Prèvosta pisząc, że ,Jeden z dyplomatów angielskich w rozmowie z korespondentem zagranicznym wyrzekł przed kilku dniami...", podczas gdy zdanie w oryginale brzmiało: „Jeden z dyplomatów, z którym rozmawiałem, powiedział:..."49. O samym autorze którego uważał za najbystrzejszego francuskiego publicystę, Rzymowski wspomniał w swoim artykule zaledwie raz:

$\mathrm{W}$ owej groźbie starcia - mówi on [Prèvost] - między najświetniejszą z dyktatur, a największą z demokracji, jakże łatwo zapominamy, że demokracje bywały odporniejsze, że nie załamują się pod porażką jednego wodza, pod błędem jednego człowieka, zapominamy, że Anglia strawiła 15 lat porażek, aby w końcu jednak powalić wielkiego Napoleona ${ }^{50}$.

Rzymowski, dodając do tekstu Prèvosta własne ozdobniki, zacierać miał ślady prowadzące do właściwego jego autora. Według ,Prosto z Mostu” akademikowi literatury nie przystoi przepisywać sobie cudzych tekstów, a sam zarzut wobec Rzymowskiego nie miałby racji bytu, w sytuacji gdyby ograniczył swój wkład jedynie do przetłumaczenia artykułu i wyraźnego zaakcentowania, że to Prèvost jest jego autorem. Pismo przypominało, że skandal przybrał już międzynarodowy charakter, a Rzymowski stał się obiektem kpin ze strony włoskiej i czeskiej prasy ${ }^{51}$.

46 J. Babiński, Obiady czwartkowe. Znów okradli p. Rzymowskiego, „Merkuriusz Polski Ordynaryjny" 1936, nr 36, s. 1070.

47 Dalsze źródła publicystyki Rzymowskiego. Nie tylko Russell, ale i Jean Prèvost, „Prosto z Mostu" 1936, nr 50, s. 4.

48 Ostatnie minuty i sekundy, „Kurier Poranny” 1935, nr 242, s. 2.

49 Dalsze źródła publicystyki Rzymowskiego..., s. 4.

50 Cyt. za tamże.

51 Tamże. 
Plagiat akademika potępiony został również w „Czasie”, w którym czytamy, że „z p. Rzymowskim nic nas nie łączy, a wszystko dzieli”, a ,jego argumenty obrończe mają, naszem zdaniem, bardzo kruche oparcie”52. „Dziennik Wileński" uważał, że Rzymowski nie miał prawa przepisywać całych ustępów cudzych tekstów, lecz co najwyżej pisać w duchu Russella ${ }^{53}$. „Dziennik Poznański” porównał go do „króla przedmieścia”, grającego główną rolę w gorszącym spektaklu, który objął „,polski Olimp literacki”. Według dziennika uczciwy pisarz nigdy nie pozwoliłby sobie na kradzież, której nie thumaczą inwektywy rzucane na krytyków, a plagiator powinien stanąć przed sądem ${ }^{54}$. Wyjątkowo krytycznie o plagiacie wypowiedział się „Przegląd Katolicki”, który uznał Rzymowskiego za „osobnika podejrzanego ideologicznie”, na co wpływ miał nie tylko jego udział w zjeździe literatów we Lwowie, lecz również cechy charakteru akademika, który według pisma jest:

niezdolnym do przejęcia się czymkolwiek, wszystkiego po kolei próbuje, a po spróbowaniu, jako pisarz, czy raczej publicysta, dzieli się nabytymi wiadomościami z czytelnikami nawet wtedy, gdy to są rzeczy z państwowego punktu widzenia niebezpieczne. [...] Jest właściwie niepoczytalnym referentem, jest bezmyślnym medium, przez które przepływają najprzeróżniejsze idee, koncepcje, pomysły, czerpane z zagranicy, i to nie dlatego, żeby się nimi przejmował i do nich się zapalał - nie, w tym człowieku, będącym marną i słabą indywidualnością, [...] płodząc dziesiątki artykułów, które, jak się okazało, z Rzymowskiego posiadały bez mała tylko jego podpis ${ }^{55}$.

Zbigniew Kucharski na łamach „Tygodnika Ilustrowanego” z 15 XI 1936 r. jako jeden z pierwszych publicystów zaatakował metody pracy dziennikarskiej nie akademika oskarżanego o plagiat, lecz S. Piaseckiego. Określił go zwolennikiem tzw. „strzelania zza płotu” do politycznych i ideologicznych oponentów. Stwierdzał, że redaktor tygodnika „Prosto z Mostu” stosuje „rewolwerową” publicystykę nastawioną na wywołanie sensacji i zdyskredytowanie Rzymowskiego poprzez złośliwą insynuację. Publicysta „Tygodnika Ilustrowanego” pytał retorycznie: „Czy p. Piasecki naprawdę nie czuje, że tego rodzaju metody poniżają raczej atakującego niż zaatakowanego, a w ogóle depczą najskromniej pojętą kulturę stosunków prasowych?" 56 .

Wśród nielicznych obrońców Rzymowskiego znalazły się „Wiadomości Literackie". Antonii Słonimski w stałej rubryce Kronika Tygodnia z 6 XII 1936 r. pisząc, że nie ma zamiaru bronić plagiatora, stwierdził jednak, że forma medialnej nagonki i „zacietrzewienie polityczne, z jakim łączą się

\footnotetext{
$52 \quad$ P. Rzymowski pod zarzutem..., s. 3.

53 P. Rzymowski się broni, „Dziennik Wileński” 1936, nr 308, s. 3.

54 „Wawrzyn” czy nożyce?, „Dziennik Poznański” 1936, nr 263, s. 12.

55 Sprawa Rzymowskiego, „Przegląd Katolicki” 1936, nr 49, s. 831.

56 Z. Kucharski, Zza płotu, ,Tygodnik Ilustrowany” 1936, nr 46, s. 874.
} 
ataki na Rzymowskiego, zaczyna przechylać moją sympatię na stronę atakowanego" "57. Słonimski nie do końca jednak znał sytuację Rzymowskiego, skoro napisał, że ,użył paru zwrotów Russella nie w utworze artystycznym ale w artykule dziennikarskim. Mógł podać nazwisko wielkiego pisarza angielskiego bez żadnej ujmy dla siebie i bez szkody dla artykułu" ${ }^{\text {, }}$, podczas gdy plagiat z Russella dotyczył fragmentów pracy Prawo do życia ..., nie artykułu dziennikarskiego. Natomiast Jerzy Stempowski w felietonie Zagadnienia plagiatu zamieszczonym 13 grudnia w „Wiadomościach Literackich” stwierdzał, że polscy dziennikarze ze zbyt wielką pewnością siebie oskarżają innych o plagiat ${ }^{59}$. Jego zdaniem w przypadku podania faktu, który jest łatwy do sprawdzenia, i oparcia argumentów na zdrowym rozsąaku:

odwoływanie się, do autorów jest zbędne i w tych wypadkach bierzemy zwykle wypowiadaną myśl na swoje sumienie. Zwyczaj ten jest oparty na ukrytej w nim przesłance, że wszystkie rozumowania, odwołujące się do zdrowego rozsądku, są dobrem publicznym i że autorem ich mógłby być każdy, kto znalazłby czas i ochotę zastanowienia się nad danym zagadnieniem. Dla tej właśnie przyczyny wyniki badań naukowych nie są objęte prawem własności literackiej ${ }^{60}$.

Według J. Stempowskiego w „,nagonce politycznej” wymierzonej w Rzymowskiego, w której przewodził S. Piasecki, redaktor „Prosto z Mostu” celowo marginalizował dorobek dziennikarski akademika, sugerując czytelnikom, że plagiat został odkryty przez przypadek, a stał się interesujący przez to, że ,p. Rzymowski jest jędrzejewiczowsko-zawitowskiej Akademii Literatury jedynym przedstawicielem publicystyki. Udał się jedynak!"'61. Z kolei według Piaseckiego obrońcy Rzymowskiego - Wanda Wasilewska i A. Słonimski - uznali, że stał się ofiarą własnych poglądów politycznych, a atak ze strony „Prosto z Mostu” jest aktem zemsty politycznej „czarnej reakcji” za udział w zjedzie lwowskim. Dla Piaseckiego „,kombinator” Rzymowski był po prostu winny plagiatu, a PAL powinna powołać specjalny sąd, aby dogłębnie wyjaśnić miałby sprawę, a następnie usunąć Rzymowskiego z Akademii ${ }^{62}$.

Plagiat stał się także przedmiotem żartów czasopism satyrycznych, w tym popularnej „Muchy”, która w numerze z 4 XII 1936 r. poświęciła akademikowi szereg krótkich fraszek. I tak w utworze Z fizyki czytamy, że Rzymowski na własnej skórze przekonał się, iż pod wpływem zimna wszystko się kurczy - gdy „wszedł do znanej kawiarni, wszyscy jego znajomi skurczyli się, udając że go nie

\footnotetext{
57 A. Słonimski, Kronika Tygodniowa, ,Wiadomości Literackie” 1936, nr 51, s. 5.

58 Tamże.

59 J. Stempowski, Zagadnienia plagiatu, ,Wiadomości Literackie” 1936, nr 52, s. 5.

60 Tamże.

61 S. Piasecki, „Nagonka polityczna”, „Prosto z Mostu” 1936, nr 51, s. 1.

62 Tamże.
} 
widzą"63. Z Przyszłego nagrobka dla Pana Wincentego Rzymowskiego dowiadujemy się, że akademik chorował na chciwość, a umarł z powodu plagiatu ${ }^{64}$. Na łamach nr 50 „Muchy” opublikowano również List Anglika (B. Russell), w którym autor Pochwaty próżniactwa ,pozwala” Rzymowskiemu „kraść i plagiatować do syta. Stary jestem, więc mam bić się z tobą, czy co?"65. W kolejnym numerze Władysław Buchner zadedykował Rzymowskiemu długą satyrę napisaną z perspektywy akademika: „Wszak wiecie, czym wojuje wrogów partia dzika? Zarzutem, iż okradłem Russella Anglika, Że ubogi w myśl własną, szedłem jego wzorem, W jego stroił się piórka, żem więc Plagiatorem!" ${ }^{66}$. Buchner w finezyjnej satyrze przytaczał argumenty mogące posłużyć „obronie” Russella, kończąc swój wiersz wymownym zwrotem: „Napiętnujcie oszczerców. Ja żądam nagrody" ${ }^{\prime 6}$.

\section{Orzeczenie Polskiej Akademii Literatury i oddźwięk w polskiej prasie}

Wobec niesłabnącej krytyki Rzymowski już 19 XI 1936 r., zatem tuż przed odkryciem drugiego plagiatu, wystosował list do Prezydium PAL prosząc o wyłonienie komisji, która zajęłaby się zbadaniem zarzutów „,w atakach owych zawartych i wydała orzeczenie o ich zasadności”. Do czasu ogłoszenia orzeczenia wstrzymał się od bieżącej działalności w Akademii ${ }^{68}$. W odpowiedzi na wezwanie oskarżonego PAL, podczas posiedzenia 19 listopada w Katowicach, ogłosiła skład członkowski sądu mającego rozstrzygnąć sprawę plagiatu. Funkcję przewodniczącego sądu pełnić miał Tadeusz Zieliński, a jego skład uzupełnili: Karol Irzykowski, Juliusz Kleiner, Bolesław Leśmian i Jerzy Szaniawski ${ }^{69}$. Według Michała Rusinka członkowie PAL chcąc ratować honor Akademii, a przy tym nie dopuścić do rezygnacji z jej członkostwa Karola Huberta Rostworowskiego, postanowili „,wymusić” na Rzymowskim rezygnację ${ }^{70}$. Ostatecznie podczas posiedzenia Akademii w dniach 23-24 I 1937 r., w którym oprócz wyżej wymienionych uczestniczyli Wacław Berent, Ferdynand Goetel, Tadeusz Boy-Żeleński, Zofia Nałkowska i Zenon Przesmycki „Miriam”, wydano oświadczenie w sprawie plagiatów, w którym czytamy:

63 Z fizyki, „Mucha” 1936, nr 50, s. 2.

64 Tamże, s. 5.

65 Tamże, s. 6.

${ }^{66}$ W. Buchner, W. Rzymowski przed polskim Sąem Polskiej Akademii Literatury, „Mucha” 1936, nr 51, s. 2.

67 Tamże.

68 Dalsze źródła publicystyki Rzymowskiego..., s. 4.

69 Sad w sprawie p. Rzymowskiego o plagiat Russela, ,Dziennik Wileński” 1936, nr 332, s. 1.

70 M. Rusinek, Moja wieża Babel, Warszawa 1982, s. 35-37. 
Zważywszy że książka W. Rzymowskiego jest zbiorem artykułów publicystycznych, że pośpiech pracy dziennikarskiej niejednokrotnie narzuca konieczność posługiwania się gotowym materiałem, sformułowanym przez publicystykę również bez podania źródła, zważywszy, że W. Rzymowski, jako wybitny stylista i autor wielu na wskroś oryginalnych prac literackich mógł był się obejść bez tego rodzaju ułatwień, uzyskując własny wyraz dla swych publicystycznych dociekań - trudno dopatrzeć się w zacytowanych w prasie zestawieniach momentu rozmyślnego plagiatu. Że jednak wybitne stanowisko, jakie W. Rzymowski zajmuje w polskim piśmiennictwie, w szczególności zaś wysoce odpowiedzialna godność członka PAL nakłada na niego obowiązek czuwania nad dobrymi obyczajami pisarskimi, PAL wyraża przekonanie, że zastosowane w tym wypadku metody pracy przez akademika literatury przyczyniają się do obniżenia powagi słowa pisanego ${ }^{71}$.

Oświadczenie PAL spotkało się z powszechną krytyką w prasie. ,,Dziennik Wileński" sugerował, że Akademia powinna odpowiedzieć na dwa fundamentalne pytania: jak bardzo rozmyślny był plagiat i czy Rzymowski powinien wciąż być jej członkiem ${ }^{72}$. W numerze pisma z 27 stycznia czytamy, że wyrok zapadł zbyt późno, Akademia przez prawie trzy miesiące grała na zwłokę, a podobne zdarzenie we Francji nie mogłoby mieć miejsca ${ }^{73}$. Ta sama gazeta oskarżała 7 lutego PAL o uznanie plagiatu za „rzecz normalną w działalności dziennikarskiej, a plagiator zasiada w dalszym ciągu jako przedstawiciel zawodu dziennikarskiego w najwyższej instytucji literackiej Rzeczypospolitej Polskiej”" . Według „Dziennika Wileńskiego” Rzymowski otrzymał fotel akademika nie za zasługi pisarskie, wybitną publicystykę, lecz za lojalną postawę wobec władz, krytykę endecji i wierne wykonywanie poleceń aktualnie rządzących. Pismo oceniało, że rezygnacja z niezależności w zamian za wysokie honoraria jest dla pisarza i publicysty największym poniżeniem ${ }^{75}$. W podobnym duchu pisał „Kurier Poznański” uważając, że instytucja powołana do czuwania nad właściwym poziomem polskiego życia literackiego wydała zalecenia idące w zupełnie innym kierunku ${ }^{76}$. „ABC” stwierdzało zaś ironicznie, że z wydaniem oświadczenia należało zaczekać do 1 kwietnia, a sam ,wyrok" Akademii jest ,laurką obrończą przystrojoną w róże” dla ,kleptomana, który wybrał życie ułatwione"77. Złośliwie o orzeczeniu PAL pisał również K. Zbyszewski

71 Oświadczenie PAL opublikowały m.in.: „Chwila” 1937, nr 6412, s. 1; „Dzień Dobry” 1937, nr 25, s. 4; „Nasz Przegląd” 1937, nr 39, s. 11; „Mały Dziennik” 1937, nr 26, s. 4; „,Robotnik” 1937, nr 25, s. 1; „Głos Poranny” 1937, nr 25, s. 3; „Gazeta Polska” 1937, nr 25, s. 4; „Dziennik Polski” 1937, nr 25, s. 1; „Dziennik Wileński” 1937, nr 24, s. 1.

72 Czy p. Rzymowski popetnit plagiat, „Dziennik Wileński” 1937, nr 24, s. 1.

73 P. Rzymowski i P.A.L., „Dziennik Wileński” 1937, nr 26, s. 3.

74 Akademia p. Rzymowskiego, „Dziennik Wileński” 1937, nr 37, s. 3.

75 Tamże.

76 Osobliwe zasady P.A.L., „Kurier Poznański” 1937, nr 43, s. 4.

77 Stańczyk, Rzymowski na P.A.L.-u. Garść plotek i przytyków, „ABC. Nowiny Codzienne” 1937, nr 32, s. 4. 
na łamach „Prosto z Mostu” twierdząc, że wyrok „w sprawie Wicusia nie jest najgorszy. Po bobkowej instytucji spodziewano się, że ogłosi Wincentego ofiarą spisku Russell - Piasecki - Prèvost i że wytoczy „Prosto z Mostu” proces o naigrywanie się ze świętości" ${ }^{78}$. Autor sugerował Rzymowskiemu konieczność emigracji do Ziemi Ognistej, gdzie mógłby pisać artykuły za 500 zł, podobnie jak w przypadku obrony „Płomyka"79.

Swój sprzeciw wyraził także Związek Dziennikarzy RP, ponieważ orzeczenie PAL nie piętnowało jednoznacznie plagiatu. Organizacja podkreśliła, że brak wskazania źródeł i autorów informacji praktykowany jest wyłącznie w prasowych działach informacyjnych. „Tolerancja ta jednak nie odnosi się w żadnym wypadku do publicystyki”, a władze Związku stanowczo potępiłyby każdy przejaw plagiatu w publicystyce ${ }^{80}$. Zgodził się z tym stanowiskiem redaktor naczelny „Dziennika Polskiego” Klaudiusz Hrabyk stwierdzając, że plagiatu nie można tłumaczyć pośpiechem pracy dziennikarskiej. Według niego Rzymowski stał się pierwszym znanym plagiatorem-publicystą, a „,dobra publicystyka” nie może być nigdy stawiana nad „,rzetelnym dziennikarstwem" $"$.

2 II 1937 r. Rzymowski zrezygnował ze stanowiska redaktora „Kuriera Porannego", zastąpił go F. Goetel ${ }^{82}$, jednak kresu atakom nie położyła nawet jego rezygnacja z członkostwa w PAL, przyjęta 27 II 1937 r. i przyznanie 4 VI 1937 r. miejsca w Akademii Kornelowi Makuszyńskiemu ${ }^{83}$.

Prasa narodowa po raz kolejny przypominała o Rzymowskim, gdy oskarżenia o plagiat wysuwano pod adresem prezesa PAL W. Sieroszewskiego ${ }^{84}$

78 K. Zbyszewski, Ryżowa szczotka, ,Prosto z Mostu” 1937, nr 6, s. 8.

79 Tamże.

80 Pośpiech akademicki P.A.L. 'u i odpowiedź Związku Dziennikarzy, „ABC. Nowiny Codzienne" 1937, nr 41, s. 1.

81 K. Hrabyk, Publicystyka i plagiat, „Dziennik Polski” 1937, nr 37, s. 3. Sam autor po ustąpieniu W. Rzymowskiego z funkcji redaktora naczelnego „Kuriera Porannego” objął w nim stanowisko redaktora politycznego.

82 Nowy naczelny redaktor „Kuriera Porannego”, „Nowy Dziennik” 1937, nr 33, s. 1.

83 Nowy akademik literatury - Kornel Makuszyński, „Gazeta Lwowska” 1937, nr 122, s. 3.

${ }^{84}$ W sierpniu 1937 r. autor podpisany jako ,T.Z. Hernes” zarzucił Sieroszewskiemu, że jego bajka Inwalidzi była bliźniaczo podobna do baśni braci Grimm Die Bremer Stadtmusikanten. Nie był to pierwszy przypadek, gdy Sieroszewski został oskarżony o plagiat. W 1929 r. Piotr Grzegorczyk pomówił przyszłego prezesa PAL o plagiat książki Pawła Piaseckiego Putešestvie po Kitaju z 1884 r., opowiadającej o podróży autora przez Syberię, Mongolię i Chiny. Dziennik ekspedycji posłużyć miał Sieroszewskiemu w pracy nad Zamorskim diabłem wydanym w 1901 r. W 1930 r. o zapożyczenia z twórczości pisarzy staropolskich w powieści Pan Twardost Twardowski oskarżali Sieroszewskiego m.in. Leon Piwiński, Andrzej Strug i A. Nowaczyński, którym nigdy nie wytoczył procesu o zniesławienie, zob. A. Nowaczyński, Po ostatnich występach pana Sieroszewskiego, ,Tęcza. Ilustrowane Pismo Miesięczne” 1937, nr 9, s. 37; Oryginalność utworów W. Sieroszewskiego, „Prosto z Mostu” 1937, nr 39, s. 4; V. Wróblewska, O gatunkowości „Bajek” Wacława Sieroszewskiego, „Acta Universitatis Nicolai Copernici. Filologia Polska” 1998, nr 325, s. 79-98. 
oraz Światopełka Karpińskiego ${ }^{85}$. Wówczas na łamach „Tęczy” głos zabrał A. Nowaczyński. Do tej pory nie komentował on sprawy plagiatów Rzymowskiego. Jak bowiem tłumaczył, mimo iż początkowo miał taki zamiar, uległ perswazjom pośredników obawiających się utraty prestiżu przez Akademię ${ }^{86}$. Po plagiacie popełnionym przez Sieroszewskiego uznał jednak, że obowiązkiem publicysty jest napiętnować „nieuleczalne warcholstwo i perfidię” zaznaczając, że i tak:

Robię już panu Sieroszewskiemu z łaski to ustępstwo, że poruszam sprawę w sezonie ogórkowym i w piśmie nie wychodzącem w stolicy, żeby sędziwemu i zbliżającemu się do kresu wędrówki człowiekowi oszczędzić wstydu i skandalu na większą skalę ${ }^{87}$.

W szczegółowej analizie wydarzeń związanych z plagiatem Rzymowskiego przypominał, że kiedy wybuchł skandal:

w Warszawie, nieśmiertelni panowie dostali ciężki orzech do zgryzienia. Robili więc wywiady na prawo i lewo, co robić z tym fantem, ratować fatalnego kolegę a z nim skompromitowany Kapitol czy też pchnąć go z Tarpejskiej skały w przepaść. Na początku wszyscy warszawscy byli za tym, żeby wybronić plagiatora, przeczekać aż «nagonka», zmęczy się i ucichnie. [...] Był moment, kiedy unisono: «nie damy Rzyma». [...] Aby okręt PALA ratować, trzeba jednak kompromitujący balast zepchnąć i wyrzucić. I dopiero kiedy «czcigodny prezes» tak zadekretował, gromadka odetchnęła z ulgą i rozeszła się po domach ${ }^{88}$.

Według Nowaczyńskiego prezes PAL Sieroszewski był najmniej kompetentną i najbardziej nieodpowiednią osobą mogącą rozstrzygnąc sprawę plagiatu czy jakikolwiek inny spór, zwłaszcza że gdy sam stanął pod zarzutem plagiatu nie wytoczył procesów swoim oskarżycielom, a jego „bezkarność” stała się jedną z pośrednich przyczyn plagiatu Rzymowskiego. Nowaczyński wytykał Sieroszewskiemu uległość wobec władz państwowych oraz prowadzenie antykościelnej nagonki, miał również o jego publicystyce zdecydowanie gorszą opinię niż o twórczości Rzymowskiego, którego dorobek cechować miała inteligencja, wielka swoboda i talent pisarski. Fundamentalną kwestię stanowiło dla Nowaczyńskiego zatem pytanie: dlaczego uzdolniony autor, posługujący się kilkoma językami i własnym, rozpoznawalnym stylem, wykorzystał w pracy cudze przemyślenia?:

Czy Russell był mu więc naprawdę takim autorytetem, że trzeba było Russella okradać? Czy nie przeczuwał odrzynając całe partie, że to wcześniej lub później odkryją, że przyjdzie nań

85 Na łamach „ABC” zarzucono Ś. Karpińskiemu, że w jednym z felietonów Emeryt Maliniak zawrzeć miał szereg motywów znanych z powieści Komediantka Władysława Reymonta. Dziennik drwił, że zrobił to ,z beztroską godną satyryka i łatwością, której pozazdrościć mogliby Rzymowski i Sieroszewski”, zob. Plagiat Karpińskiego z Reymonta. Następcy Wicusia rodza się na kamieniu, „ABC. Nowiny Codzienne” 1937, nr 291, s. 4.

86 A. Nowaczyński, Po ostatnich występach..., s. 31.

87 Tamże.

88 Tamże. 
krach a potem kompromitacja i tych grup, które go ostatnio odnajęły i którym się wysługiwał. Otóż właśnie, że nie, że nie przeczuwał a nawet może przeczuwając decydował się na «wściekłe ryzyko» plagiatu, przekonawszy się, że plagiowanie, plagiat nawet udowodniony nie pociąga za sobą u nas żadnych konsekwencji przykrych i szkodliwych dla plagiatora... stwierdził naocznie, że nad zarzutami o plagiowanie (o ile się jest asekurowanym w miarodajnym obozie) opinia publiczna przechodzi do porządku dziennego ${ }^{89}$

odpowiadał sam sobie Nowaczyński.

Orzeczenie PAL w sprawie Rzymowskiego zainspirowało satyryczne pisma do stworzenia kolejnych, niewybrednych fraszek i wierszy. W ,Szarży” z 14 lutego napisano:

Polska jest cała podzielona na części trzy, z których jedną zamieszkuje... (W tej chwili red. „Szarży” spostrzega, iż jest to wstęp do pamiętników Cezara - prosimy wybaczyć znanemu Akademikowi, ze względu na świetny styl. Pośpiech pracy dziennikarskiej... - patrz. orzeczenie P.A.L'u) ${ }^{90}$.

Z kolei „Mucha” z 18 czerwca skomentowała wybór Makuszyńskiego na nowego członka Akademii satyrą Nie zrobiliśmy interesu W. Buchnera:

bo proszę tylko zważyć ciężar gatunkowy jednego akademika i drugiego. Pan Wincenty Rzymowski jest typem szczególnym, wygląda, jak żółć, podlana kwasem, pan Kornel Makuszyński jest typem ogólnym, wygląda, jak cukierek, podlany czekoladą ${ }^{91}$.

W numerze „Muchy” z 27 VIII 1937 r. ukazała się wierszowana wymiana korespondencji między Rzymowskim a Sieroszewskim, z której wynika, że prezesa PAL, „niania, Grimm i bajki strasznie parzą w pięty" ". Rzymowski wystąpił także w Szopce niepolitycznej „Prosto z Mostu”, wcielając się w postać Adama wygnanego, wypowiadającego gorzkie słowa:

Do raju trafić nie mogę,

Bom przez grzech stracił drogę!

W Rajum miał dość rozkoszy,

Złote na polach kłosy.

Nigdym nie umiał orać,

Za wołami: heja - wołać ${ }^{93}$.

Rezygnacja W. Rzymowskiego z członkostwa w PAL wzbudziła sprzeciw redaktora „Wiadomości Literackich”. M. Grydzewski w numerze z 21 III 1937 r. pisał, że Rzymowski padł ofiarą kampanii politycznej:

Jasną jest rzeczą, że skoro w sprawie o plagiat, wyrok Akademii winy Rzymowskiego nie uznał za tak ciężką, aby go z grona swego usunąć, Akademia rezygnacji tej ze względów

89 Tamże, s. 35-36.

90 Akademik Wincenty Rzymowski, ,Szarża” 1937, nr 8, s. 5.

91 W. Buchner, Nie zrobiliśmy interesu, „Mucha” 1937, nr 26, s. 2.

92 Wacław Sieroszewski do Wincentego Rzymowskiego, „Mucha” 1937, nr 36, s. 5.

${ }^{93}$ J. Srokowski, Szopka niepolityczna. ,Pastorałka” L. Schillera w nowej obsadzie (teksty autentyczne), „Prosto z Mostu” 1938, nr 55-56, s. 13. 
czysto koleżeńskich nie powinna była w następstwie przyjąć. [...] Ale tak czy inaczej, rezygnacja Rzymowskiego, nawet po przyjęciu jej przez Akademię jest formalnie nieważna ${ }^{94}$. Grydzewski na potwierdzenie swych słów przytoczył zapis art. 10 z Rozporządzenia Rady Ministrów z dn. 29 IX 1933 r., powołującego do życia PAL, w myśl którego:

Członek Polskiej Akademii Literatury może być pozbawiony swej godności jeżeli popełnił czyn hańbiący, bądź też jeżeli działał na niekorzyść państwa polskiego. Pozbawienie godności akademika dokonane być może łącznym zarządzeniem prezesa rady ministrów i ministra wyznań religijnych i oświecenia publicznego na podstawie uchwały Akademii95. Tym samym Grydzewski przekonywał czytelnika, że przynależność do PAL jest dożywotnia, każdy jej członek staje się ,,pomazańcem literackim”, a wybór jego następcy łamie statut Akademii ${ }^{96}$. Opinie redaktora „Wiadomości Literackich” spotkały się z natychmiastową reakcją ze strony tygodnika „Prosto z Mostu”. Piasecki uznał Grydzewskiego za ,kauzyperdę” pomijającego casus cenionego pisarza i wolnomularza Andrzeja Struga, który w 1934 r. odmówił przyjęcia członkostwa w PAL. Ponadto zaliczył go do grona ,żarliwych obrońców” Rzymowskiego pisząc: ,cóż się potem dziwić, że w młodszym pokoleniu literackim (tym kawiarnianym oczywiście) plaga plagiatu szerzy się w najlepsze"97. Nie przejmując się tymi uwagami Grydzewski zasięgnął opinii znanego francuskiego prawnika Maurice’a Garçona, zajmującego się literaturą, który stwierdził, że „Akademia Francuska w żadnym wypadku nie przewiduje zastąpienia członka, który został wykluczony lub który ustąpił"98. Opinia Garçona przytoczona przez ,Wiadomości Literackie” nie miała jednak wpływu na wybór K. Makuszyńskiego na nowego członka PAL.

Po ustąpieniu Rzymowskiego z funkcji redaktora naczelnego ,Kuriera Porannego", rezygnacji z członkostwa w PAL i zajęciu się prowadzeniem wypożyczalni książek, prasa narodowa sądziła, że kariera byłego akademika zakończyła się definitywnie. W późniejszych latach pojawiały się głosy, że padł on ofiarą spisku politycznego, za którym stali czołowi działacze konsolidującego się Obozu Zjednoczenia Narodowego, dążącego do pozyskania młodzieżowych środowisk skrajnej prawicy ${ }^{99}$. Rzymowski nie zrezygnował jednak z dotychczasowej działalności politycznej angażując się w prace Klubu

94 M. Grydzewski, Czy Rzymowski przestał być członkiem Akademii?, „Wiadomości Literackie" 1937, nr 13, s. 7.

95 Cyt. za: M. Grzydzewski, dz. cyt.

96 Tamże.

97 S. Piasecki, Przegląd prasy. Zastanawiający zbieg okoliczności, „Prosto z Mostu” 1937, nr 14, s. 5.

98 M. Garçon, Czy można przestać być członkiem Akademii? Głos znakomitego prawnika francuskiego. Potwierdzenie tezy „Wiadomości Literackich”, „Wiadomości Literackie” 1937, nr 19, s. 7.

99 K. Koźniewski, Historia co tydzień. Szkice o tygodnikach społeczno-kulturalnych, Warszawa 1976, s. 261. 
Demokratycznego, który przerodził się później w Stronnictwo Demokratyczne. Po wybuchu II wojny światowej przybył do Moskwy na zaproszenie W. Wasilewskiej i został aktywnym członkiem Związku Patriotów Polskich, a następnie Polskiego Komitetu Wyzwolenia Narodowego, w którym pełnił funkcję kierownika Resortu Kultury i Sztuki. W tym okresie w pismach konspiracyjnych $^{100}$ i zagranicznych ukazywały się krytyczne artykuły na temat Rzymowskiego, przypominające jego plagiat. Londyński „Dziennik Polski i Dziennik Żołnierza" w związku z podpisaniem przez niego 16 X 1945 r. w Waszyngtonie Karty Narodów Zjednoczonych przedrukował wystąpienie, które w Izbie Reprezentantów wygłosił senator Alvin O'Konski przypominając plagiat Rzymowskiego. Senator porównywał byłego akademika do Vidkuna Quislinga, norweskiego kolaboranta z czasów II wojny światowej, mówiąc, że:

gdy istniał prawdziwy rząd Polski, Wincenty Rzymowski był zwolennikiem tego rządu.

Gdy w Polsce ustanowiono marionetkowy rząd sowiecki, Wincenty Rzymowski stał się również jego zwolennikiem. W sercu jego nie ma lojalności i patriotyzmu, toteż przejdzie on do historii jako polski quisling najgorszego gatunku ${ }^{101}$.

Paradoksem historii pozostaje fakt, że członek PAL W. Rzymowski, autor plagiatów z tekstów B. Rusella i J. Prèvosta, których odkrycie zmusiło go do ustąpienia z Akademii i stanowiska redaktora naczelnego „Kuriera Porannego”, kilka lat później objął Ministerstwo Kultury i Sztuki w Rządzie Tymczasowym Rzeczypospolitej Polskiej. Następnie pełnił funkcję ministra spraw zagranicznych w Tymczasowym Rządzie Jedności Narodowej i ministra bez teki w rządzie Józefa Cyrankiewicza, pozostając do końca życia politykiem na usługach komunistycznej władzy. Natomiast redaktor naczelny „Prosto z Mostu” S. Piasecki i odkrywca plagiatu J. Mosdorf zginęli w czasie wojny rozstrzelani przez hitlerowców. Pierwszy 12 VI 1941 r. w Palmirach w zbiorowej egzekucji przedstawicieli polskiej inteligencji, drugi - 11 X 1943 r. w obozie KL Auschwitz.

\section{Bibliografia}

Prasa

Agentura obcej myśli. Czas skończyć z rzymowszczyzna, „ABC. Nowiny codzienne” 1936, nr 321, s. 2.

Akademia p. Rzymowskiego, „Dziennik Wileński” 1937, nr 37, s. 3.

Akademik Wincenty Rzymowski, ,Szarża” 1937, nr 8, s. 5.

Babiński J., Obiady czwartkowe. Znów okradli p. Rzymowskiego, „Merkuriusz Polski Ordynaryjny" 1936, nr 36, s. 1069-1072.

100 Plagiat dzieła B. Russella został przypomniany w artykule Panowie z P.K.W.N., „Wieści” 1944, nr 6, s. 1.

101 Warszawa nie uznaje sojuszu z W. Brytania. Kompromitujace wystapienie Rzymowskiego w Waszyngtonie, „Dziennik Polski i Dziennik Żołnierza” 1945, nr 255, s. 1. 
Bezwstydny Russel. „Akademik” Rzymowski „ofiara” plagiatu angielskiego autora, „Ilustrowany Kurier Codzienny" 1936, nr 312, s. 5.

Bobki nie wystarcza, ,ABC. Nowiny codzienne” 1936, nr 333, s. 3.

Broncel Z., To, czego nie było w sprawozdaniu P.A.L.-u, „Prosto z Mostu” 1936, nr 49, s. 4.

Buchner W., Nie zrobiliśmy interesu, „Mucha” 1937, nr 26, s. 2.

Buchner W., W. Rzymowski przed polskim Sądem Polskiej Akademii Literatury, „Mucha” 1936, nr 51, s. 2.

Czemu stuży „Ptomyk”, „Kurier Poranny” 1936, nr 76, s. 6.

Czy akademik Rzymowski popetnit plagiat?, „Chwila” 1936, nr 6336, s. 4.

Czy p. Rzymowski popetnit plagiat, „Dziennik Wileński” 1937, nr 24, s. 1.

Dalsze źródła publicystyki Rzymowskiego. Nie tylko Russell, ale i Jean Prèvost, „Prosto z Mostu" 1936, nr 50, s. 4.

Echa plagiatu zagranica, ,Warszawski Dziennik Narodowy” 1936, nr 318B, s. 4.

Garçon M., Czy można przestać być członkiem Akademii? Głos znakomitego prawnika francuskiego. Potwierdzenie tezy „Wiadomości Literackich”, „Wiadomości Literackie" 1937, nr 19, s. 7.

Grydzewski M., Czy Rzymowski przestał być członkiem Akademii?, „,Wiadomości Literackie" 1937, nr 13, s. 7.

Hrabyk K., Publicystyka i plagiat, „Dziennik Polski” 1937, nr 37, s. 3.

Kucharski Z., Zza płotu, ,,Tygodnik Ilustrowany” 1936, nr 46, s. 874.

Ładosz H., „Tajny detektyw” dmucha, „Kurier Poranny” 1936, nr 76, s. 6.

Marczewska H., W otwarte karty, „Kurier Poranny” 1936, nr 76, s. 6.

Na marginesie, „Prosto z Mostu” 1935, nr 40, s. 6.

Na marginesie, „Prosto z Mostu” 1936, nr 29, s. 1.

Nagrobek sobie samemu, „Ilustrowany Kurier Codzienny” 1936, nr 325, s. 15.

Nowaczyński A., Po ostatnich występach pana Sieroszewskiego, „Tęcza. Ilustrowane Pismo Miesięczne" 1937, nr 9, s. 31-38.

Nowy akademik literatury - Kornel Makuszyński, „Gazeta Lwowska” 1937, nr 122, s. 3.

Nowy naczelny redaktor „Kuriera Porannego”, „Nowy Dziennik” 1937, nr 33, s. 1.

Oryginalność utworów W. Sieroszewskiego, „Prosto z Mostu” 1937, nr 39, s. 4.

Osobliwe zasady P.A.L., „Kurier Poznański” 1937, nr 43, s. 4.

Ostatnie minuty i sekundy, „Kurier Poranny” 1935, nr 242, s. 2.

P. Rzymowski i P.A.L., ,Dziennik Wileński” 1937, nr 24, s. 3.

P. Rzymowski pod zarzutem, „Czas” 1936, nr 309, s. 3.

P. Rzymowski się broni, „Dziennik Wileński” 1936, nr 308, s. 3.

P. Rzymowski się ttumaczy, „ABC. Nowiny Codzienne” 1936, nr 322, s. 2.

Panowie z P.K.W.N., ,Wieści” 1944, nr 6, s. 1.

Piasecki S., Front sowiecki i front polski, „Prosto z Mostu” 1936, nr 23, s. 1.

Piasecki S., Jak powstało „Prosto z mostu”, „Prosto z Mostu” 1935, nr 1, s. 1.

Piasecki S., „Nagonka polityczna”, „Prosto z Mostu” 1936, nr 51, s. 1. 
Piasecki S., Przegląd prasy. Zastanawiający zbieg okoliczności, „Prosto z Mostu” 1937, nr 14, s. 5.

Piasecki S., Wawrzyn akademicki przedstawia się..., „Prosto z Mostu” 1935, nr 47, s. 1.

Plagiat Karpińskiego z Reymonta. Następcy Wicusia rodza się na kamieniu, „ABC. Nowiny Codzienne" 1937, nr 291, s. 4.

Pobożne zyczenia K.A.P.-u, „Kurier Poranny” 1936, nr 76, s. 6.

Pośpiech akademicki P.A.L.' u i odpowiedź Związu Dziennikarzy, „ABC. Nowiny Codzienne" 1937, nr 41, s. 1.

„Prosto z Mostu”. Bertrand Russell plagiatorem?, „Kurier Nowogrodzki” 1936, nr 307, s. 7.

Pruszyński K., ,,Pomiędzy Marksem a ... każdorazowym premierem”, ,, Akademik literatury” Wincenty Rzymowski w świetle faktów. Do Pana Mariana Dąbrowskiego, Naczelnego Redaktora „IKC” list otwarty, „Ilustrowany Kurier Codzienny” 1936, nr 169, s. 2-3.

Przegląd prasy, „Warszawski Dziennik Narodowy” 1936, nr 335B, s. 3.

Przepowiednie na rok 1937, „ABC. Nowiny Codzienne” 1937, nr 3, s. 8.

Rzymowski plagiatorem, „Warszawski Dziennik Narodowy” 1936, nr 307B, s. 2.

Rzymowski W., Bandycka napaść „Prosto z mostu”, „Kurier Poranny” 1936, nr 311, s. 5.

Rzymowski W., Ostatnie minuty i sekundy, ,Kurier Poranny” 1935, nr 242, s. 2.

Rzymowski W., „Płomyk” światta i chmura mroku, „Kurier Poranny” 1936, nr 76, s. 1.

Rzymowski W., Pod adresem p. Piaseckiego, „Kurier Poranny” 1936, nr 311, s. 6.

S.H. [Samuel Hirszhorn], Przez skandal do postępu! „Nasz Przegląd” 1936, nr 334, s. 3.

Sąd w sprawie p. Rzymowskiego o plagiat Russela, „Dziennik Wileński” 1936, nr 332, s. 1.

Słonimski A., Kronika Tygodniowa, „Wiadomości Literackie” 1936, nr 51, s. 5.

Sprawa p. Rzymowskiego. Sąd honorowy orzeknie, czy plagiat jest czynem haniebnym, „ABC. Nowiny Codzienne” 1936, nr 337, s. 1.

Sprawa Rzymowskiego, „Przegląd Katolicki” 1936, nr 49, s. 831.

Srokowski J., Szopka niepolityczna. „Pastorałka” L. Schillera w nowej obsadzie (teksty autentyczne), „Prosto z Mostu” 1938, nr 55-56, s. 13.

Stańczyk, Rzymowski na P.A.L.-u. Garść plotek i przytyków, „ABC. Nowiny Codzienne” 1937, nr 32, s. 4.

Stempowski J., Zagadnienia plagiatu, „Wiadomości Literackie” 1936, nr 52, s. 5.

Wacław Sieroszewski do Wincentego Rzymowskiego, „Mucha” 1937, nr 36, s. 5.

Warszawa nie uznaje sojuszu z W. Brytania. Kompromitujace wystąienie Rzymowskiego w Waszyngtonie, „Dziennik Polski i Dziennik Żołnierza” 1945, nr 255, s. 1.

„Wawrzyn” czy nożyce?, „Dziennik Poznański” 1936, nr 263, s. 12.

Witowski A. [właść.: Jan Mosdorf], Bertrand Russel plagiatorem?, „Prosto z Mostu” 1936, nr 47, s. 1.

Witowski A. [właść.: Jan Mosdorf], W okopach zeszłego stulecia, „Prosto z Mostu” 1936, nr 42, s. 7. 
Wycinanki, ,Prosto z Mostu” 1936, nr 28, s. 3.

Z fizyki, „Mucha” 1936, nr 50, s. 2.

Zbyszewski K., Ryżowa szczotka, ,Prosto z Mostu” 1937, nr 6, s. 8.

Zwrot w sprawie Rzymowskiego. Akademia Literatury powołała specjalna komisje, „ABC.

Nowiny Codzienne" 1936, nr 336, s. 1.

Opracowania

Chmielewska L., Wincenty Rzymowski (1883-1950). Biografia publicysty i polityka, Toruń 2007.

Koźniewski K., Historia co tydzień. Szkice o tygodnikach społeczno-kulturalnych, Warszawa 1976.

Łętocha R., „Prosto z Mostu” - pismo i środowisko, [w:] Prasa Narodowej Demokracji 1886-1939, red. A. Dawidowicz, E. Maj, Lublin 2010, s. 111-125.

Missuna O., Warszawski pitaval literacki, Warszawa 1960.

Rusinek M., Moja wieża Babel, Warszawa 1982.

Russell B., Pochwała próżniactwa, Warszawa 1937.

Rzymowski W., Prawo do życia a powinność pracy, Warszawa 1936.

Tobera M., „Antyskamandryta” (Stanisław Piasecki), „Kwartalnik Historii Prasy Polskiej” 1992, t. 31, nr 3-4, s. 188-195.

Urbanowski M., „Fanatyk patriotyzmu” - portret Stanisława Piaseckiego, [w:] S. Piasecki, Prosto z mostu. Wybór publicystyki literackiej, wybór i oprac. M. Urbanowski, Kraków 2003, s. 87-98.

Urbanowski M., O Stanisławie Piaseckim i jego krytyce literackiej, [w:] M. Urbanowski, Prawa strona literatury polskiej. Szkice i portrety, Kraków 2007, s. 7-49.

Wróblewska V., O gatunkowości „Bajek” Wacława Sieroszewskiego, „Acta Universitatis Nicolai Copernici. Filologia Polska” 1998, nr 325, s. 79-98. 